\title{
Rheumatic disorders in primary biliary cirrhosis
}

\author{
A. K. ClaRKE, R. M. GALbRAith, E. B. D. HAMilton, AND R. Williams
}

From the Department of Rheumatology and Rehabilitation, and the Liver Unit, King's College Hospital, Lond㠃

SUMMARY Eighty-three patients with primary biliary cirrhosis were investigated to determine the prevalence of rheumatic disorders. 14 had scleroderma, which tended to be mild but in severgl patients produced severe systemic manifestations. The CRST syndrome (calcinosis, Raynauds phenomenon, sclerodactyly, telangiectasia) was only identified twice. There was an increased incidence of HLA A1+B8 in those patients with scleroderma. As well as those with scleroderma, 4 patients had a destructive arthropathy resembling avascular necrosis. 4 patients had an inflari matory arthritis, without specific features, but the frequency was no greater than might be expectẹd in the general population.

Multisystem involvement is a frequent feature of primary biliary cirrhosis, particularly in the form of keratoconjunctivitis sicca or of a renal tubular acidification defect (Golding et al., 1973). Arthropathy and other rheumatic disorders are a less common accompaniment, but the finding in patients of scleroderma, usually as the CRST syndrome (calcinosis cutis, Raynaud's phenomenon, sclerodactyly, and telangiectasia), has been reported (Murray-Lyon et al., 1970; Reynolds et al., 1971; August, 1974) We describe a systematic survey for rheumatological involvement in 83 consecutive patients with primary biliary cirrhosis seen at this hospital over the past 7 years.

\section{Patients and methods}

The diagnostic criteria in the 83 patients investigated included liver biopsy appearances with histological changes of chronic nonsuppurative destructive cholangitis. In all but one patient, who had no evident rheumatic disorder, mitochondrial antibodies were found in the serum by immunofluorescence (Walker et al., 1965). 73 of the patients were females with a mean age of 54 years (range 28-76 years) at the time of presentation, and 10 were males with a mean age of 58 years (range 48-67 years). These cases formed a consecutive series of patients referred to us between 1969 and 1976.

A full rheumatological examination was carried

Accepted for publication July 5, 1977

Correspondence to $\mathrm{Dr}$ A. K. Clarke, Royal National Hospital for Rheumatic Diseases, Upper Borough Walls, Bath BA1 1RL out in every patient on at least one occasion. Where clinically indicated, joint radiographs as well gos barium swallow and lung function tests for evidene of scleroderma were performed. In those patients in whom the diagnosis of scleroderma remained in doubt, skin biopsy was performed. Testing $\mathrm{f}$ f keratoconjunctivitis sicca was carried out as \$opeviously described (Golding et al., 1973). Sera 갈e

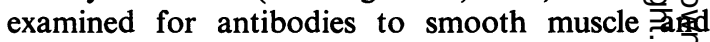
nuclei by immunofluorescence (Walker et al., 196ङ) and to extractable nuclear antigen by haemagglutinântion (anti-ENA) (Sharp et al., 1972). Tissue typi\$g was carried out using a microtoxicity techniqge (Batchelor, 1973). No patient had received corticgsteroids but 72 were participating in an international controlled clinical trial of azathioprine against placebo.

\section{Results}

Evidence of a rheumatic disorder was found in $\$ 3$ of the 83 patients, the commonest being sclerodern which was present in 14 patients (Table). 2 of the $\$ 4$ (Cases 11 and 12) have previously been reported by us (Murray-Lyon et al., 1970) and another (Case by Morgan (1973). The full spectrum of sclerodern was encountered although in the majority of patierfs it was mild. 5 had no evidence of systemic involves ment and the skin involvement was not marked, with no severe loss of finger pulp. Only one in this nonsystemic group had evidence of acrolysis on radiography (Fig. 1) and none had calcinos Similarly, although a number of patients had tighteening of the facial skin there was no case of trite microstomia. 
Table Details of patients with primary biliary cirrhosis and scleroderma

\begin{tabular}{|c|c|c|c|c|c|c|c|c|c|c|c|}
\hline \multirow{2}{*}{$\begin{array}{l}\text { Case } \\
\text { no. }\end{array}$} & \multirow[t]{2}{*}{ Sex } & \multirow{2}{*}{$\begin{array}{l}\text { Age at } \\
\text { presentation } \\
\text { (years) }\end{array}$} & \multirow{2}{*}{$\begin{array}{l}\text { Cutaneous } \\
\text { manifestations }\end{array}$} & \multirow{2}{*}{$\begin{array}{l}\text { Hand } \\
\text { radiographs }\end{array}$} & \multicolumn{2}{|c|}{ Oesophagus } & \multirow{2}{*}{$\begin{array}{l}\text { Lung } \\
\text { function }\end{array}$} & \multirow{2}{*}{$\begin{array}{l}H L A \\
1+8\end{array}$} & \multirow[t]{2}{*}{$A N A$} & \multirow[t]{2}{*}{ Anti-ENA } & \multirow{2}{*}{$\begin{array}{l}\text { Sicca } \\
\text { syndrome }\end{array}$} \\
\hline & & & & & Varices & $\overline{M o t i l i t y}$ & & & & & \\
\hline 1 & $\mathbf{M}$ & 56 & $\mathbf{S}$ & Normal & + & Normal & Normal & Not done & - & - & + \\
\hline 2 & $\mathbf{F}$ & 45 & S & . & + & , & , & Not done & - & Not done & + \\
\hline 3 & $\mathrm{~F}$ & 44 & RS & ", & - & ", & $"$ & - & $\begin{array}{c}\text { Diffuse } 1 / 80, \\
\text { transient }\end{array}$ & - & + \\
\hline 4 & $\mathbf{F}$ & 62 & RS & ", & - & , & $\because$ & + & $\begin{array}{c}\text { Diffuse } 1 / 160, \\
\text { transient }\end{array}$ & - & + \\
\hline 5 & $\mathbf{F}$ & 67 & RS & , & - & Reduced & $\begin{array}{l}\text { Airways } \\
\text { obstruction }\end{array}$ & + & Diffuse $1 / 10$ & - & $\begin{array}{l}\text { Not } \\
\text { done }\end{array}$ \\
\hline 6 & $\mathbf{F}$ & 62 & RS & Acrolysis & - & Normal & Normal & + & $\begin{array}{c}\text { Nucleolar } \\
1 / 1000\end{array}$ & $\begin{array}{l}\text { Anti- } \\
\text { nucleolar } \\
\text { RNP } \\
\text { antibodies }\end{array}$ & + \\
\hline 7 & $\mathbf{F}$ & 53 & ST & Normal & - & Absent & $\begin{array}{l}\text { Reduced gas } \\
\text { transfer }\end{array}$ & - & - & - & + \\
\hline 8 & $\mathbf{F}$ & 53 & RST & : & + & Absent & Normal & - & $\begin{array}{c}\text { Diffuse } 1 / 16 \\
\text { transient }\end{array}$ & Not done & + \\
\hline 9 & $\mathbf{F}$ & 53 & RST & , & - & Reduced & $\begin{array}{l}\text { Reduced gas } \\
\text { transfer }\end{array}$ & + & - & Not done & + \\
\hline 10 & $\mathbf{F}$ & 61 & CRST & Calcinosis & + & Absent & Normal & + & Diffuse $1 / 10$ & - & + \\
\hline 11 & $\mathbf{F}$ & 64 & RST & Acrolysis & - & Absent & $\begin{array}{l}\text { Reduced gas } \\
\text { transfer }\end{array}$ & Not done & Speckled $1 / 10$ & Not done & $\begin{array}{l}\text { Not } \\
\text { done }\end{array}$ \\
\hline 12 & $\mathbf{F}$ & 62 & CRST & $\begin{array}{l}\text { Acrolysis, } \\
\text { calcinosis }\end{array}$ & - & Reduced & Not done & Not done & Speckled $1 / 10$ & $\begin{array}{l}\text { Anti- } \\
\text { nuclear } \\
\text { RNP } \\
\text { antibodies }\end{array}$ & $"$ \\
\hline 13 & F & 31 & RST & Normal & - & Reduced & $\begin{array}{l}\text { Reduced gas } \\
\text { transfer }\end{array}$ & - & - & - & ", \\
\hline 14 & $\mathbf{F}$ & 59 & & $\begin{array}{l}\text { Periarticular } \\
\text { osteoporosis }\end{array}$ & - & Absent & Normal & - & - & - & - \\
\hline
\end{tabular}

$\mathrm{C}=$ calcinosis $; \mathbf{R}=$ Raynaud's; $\mathbf{S}=$ sclerodactyly $; \mathbf{T}=$ telangiectasia.

ANA = antinuclear antibodies; anti-ENA = extractable nuclear antigen; $R N P=$ ribonucleoprotein.

Of those patients with systemic scleroderma, the majority had benign disease, mainly confined to loss of peristalsis of the oesophagus and some reduction in gas transfer in the lungs. However, one patient, (Case 13) had rapidly progressive disease. She presented with a short history of pruritis, pigmentation, and slight jaundice, and was noted to have

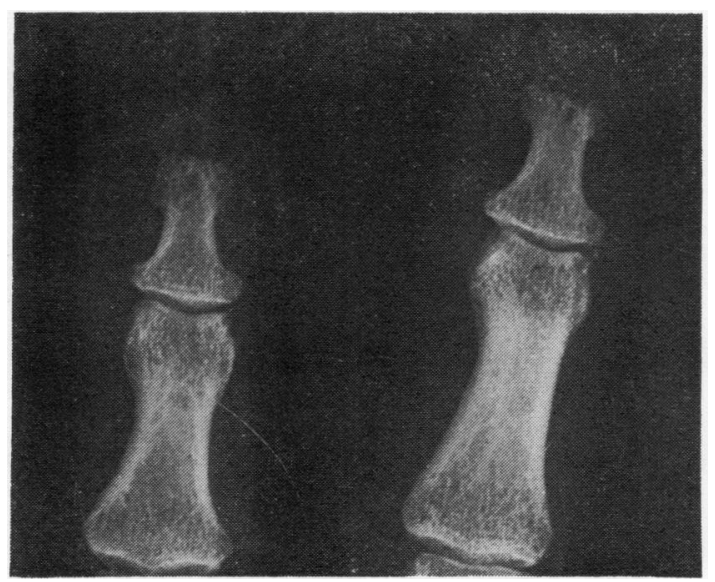

Fig. 1 Case 6. Radiograph of right index and middle fingers showing acrolysis.
Raynaud's phenomenon, thickening of the skin of the fingers, and well marked telangiectasia on the face and fingers. She developed rapidly progressive cardiac failure due to cardiomyopathy. Cardiac catheterisation showed high right-sided pressures $(50 / 18 \mathrm{mmHg})$ in the presence of normal pulmonary artery pressures $(28 / 8 \mathrm{mmHg})$. The right ventricle was seen to be dilated on angiographic examination and an endocardial biopsy performed by Dr P. Richardson showed the presence of hypertrophy histologically. Despite treatment with digoxin and diuretics, the patient deteriorated rapidly over several weeks and died in cardiopulmonary failure. Post-mortem examination showed sclerodermatous involvement of heart, oesophagus, and the kidneys.

One patient (Case 14) had atypical scleroderma. She had suffered from psoriasis for 7 years before presentation in 1970, together with a mild seronegative arthropathy, fairly typical of that seen in psoriasis. for 2 years. She presented with severe chest pain and haematemesis caused by a rupture of the oesophagus. The oesophagus was nonmotile and a biopsy taken at the time of repair of the rupture was typical of scleroderma. She had no skin manifestations of scleroderma. A diagnosis of primary biliary cirrhosis was also made at this time on the basis of circulating mitochondrial antibodies and a 
positive liver biopsy. Since then her liver disease has not progressed but she has had recurrent episodes of swelling of the knees and more recently atlantoaxial subluxation with a distance of $7.5 \mathrm{~mm}$ between the front of the odontoid peg and the atlas on full flexion. Both of these appear to be manifestations of her psoriatic arthritis.

In those patients with evidence of systemic involvement the skin changes were fairly mild, only 2 patients having the full CRST syndrome and only 2 with acrolysis. It is of interest that all except 2 of this group had telangiectasia. Full details of the patients are given in the Table.

Other rheumatological disorders were much less common. In 4 patients we found a destructive arthropathy. The first (Case 16) developed severe pain with limitation in both shoulders 5 months after diagnosis of primary biliary cirrhosis. Radiographs showed gross destruction of both humeral heads (Fig. $2 a, b$ ). The other 3 patients had hip disease, in one case bilateral. Radiographs showed gross destruction of the femoral heads with new bone formation (Fig. 3). 2 of these patients had hip replacements and, in all 3 specimens obtained,

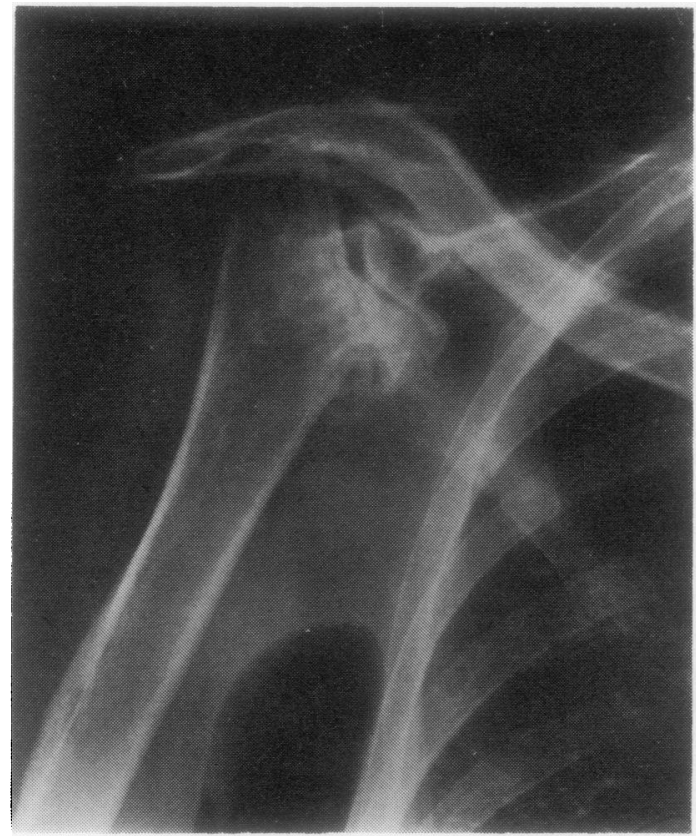

(a) histological examination showed advanced ostêㅇarthrotic changes only. None of the 4 had abnormatly high cholesterol levels and none had receied corticosteroids for any reason.

An inflammatory arthritis was found in 4 patiens, including Case 14 who had scleroderma of the oesophagus with psoriatic arthropathy, mentioned above. All were female. The first presented wit small joint polyarthritis in the hands and feet whth marked morning stiffness. Rheumatoid factor present at a titre of 1 in 64 and antinuclear antibcoly at 1 in 160. There were no radiological erosions or subcutaneous nodules. Routine liver function tests were abnormal and she was found to have primaty biliary cirrhosis. The arthropathy improved oves a period of 9 months and had disappeared entirgly without treatment at the time of her death. The other 2 patients had an erosive arthropathy, and both were seronegative. The first had a persistent arthritistof the hands lasting 11 months until her death 30 months after diagnosis of primary biliary cirrhosis, while the other had a painful, swollen ankle whiकh completely resolved after a local steroid injecti\&n. Liver function tests were abnormal at this time and primary biliary cirrhosis was diagnosed.

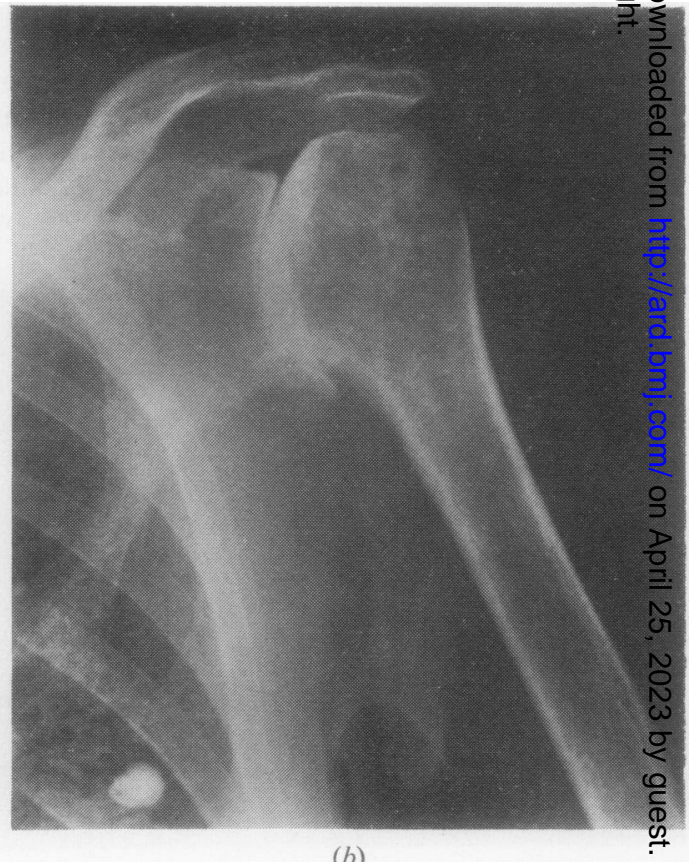

(b)

Fig. 2 Case 16. Severe destructive arthropathy in right (a) and left (b) shoulders of same patient. 


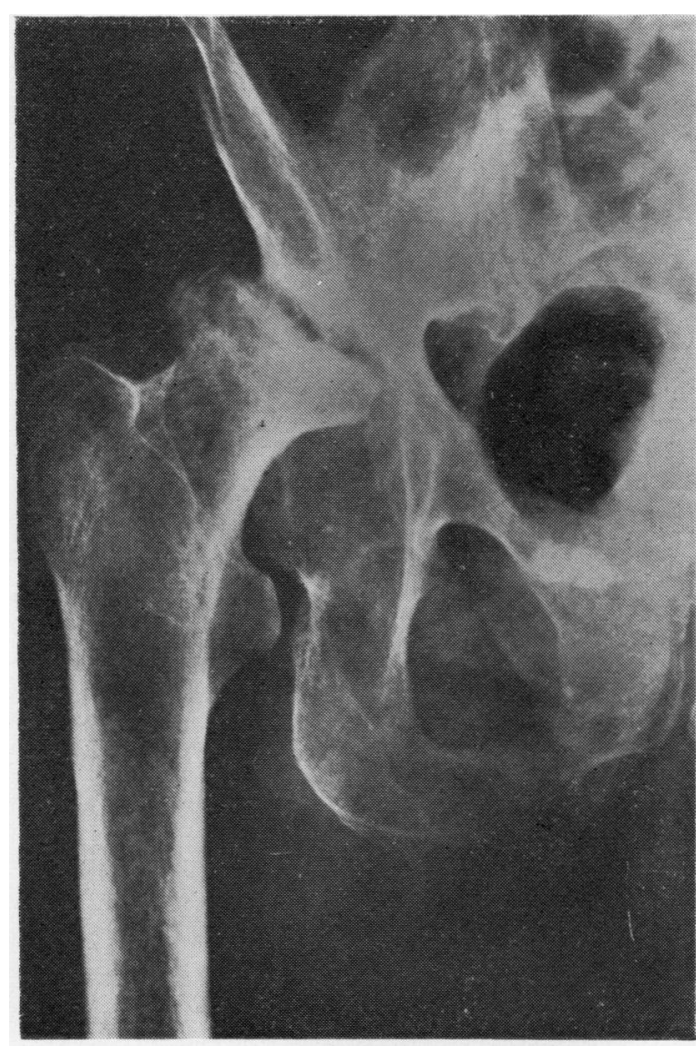

Fig. 3 Severe destructive arthropathy in hip joint.

Two other patients had what might be described as rheumatic complaints. One had a classical shoulder-hand syndrome with no evidence of underlying arthritis, while the second had a painful hip due to Paget's disease of the acetabulum and femoral head.

Antibodies to extractable nuclear antigen were looked for in 11 of the 14 scleroderma patients (Table). 2 out of the 5 with positive antinuclear antigens tested showed the presence of anti-ENA of the antiribonuclear protein type. Keratoconjunctivitis sicca was present in 9 of the 10 patients with scleroderma tested (Table), the patient with no such evidence being Case 14 who had isolated oesophageal disease and psoriatic arthritis. This frequency of sicca syndrome compares with $53 \%$ in the patients with primary biliary cirrhosis as a whole (Golding et al., 1973).

Tissue typing was performed in 10 of the 14 scleroderma patients (Table). 5 had the combination of HLA A1 and B8 compared to $17 \%$ frequency in 89 healthy controls. This is a significant excess of these antigens $(P<0.01)$ and is also in excess of the frequency found in the biliary cirrhosis group (33\%).

\section{Discussion}

The most striking finding in this study was the high prevalence of scleroderma in our patients with primary biliary cirrhosis. In earlier studies (Bartholomew et al., 1964; D'Angelo et al., 1969) this association was disputed since surveys of patients with scleroderma showed negligible numbers with chronic liver disease. However, in the few systematic studies where primary biliary cirrhosis has been the index disease, the association has been confirmed (Sherlock and Scheuer, 1973; Buffet and Etienne, 1975) and there are several reports of individuals with both diseases (Murray-Lyon et al., 1970; Reynolds et al., 1971; O'Brien et al., 1972). Nevertheless, the prevalence of scleroderma in our study $(17 \%)$ was noticeably higher than the $3 \%$ found by Sherlock and Scheuer (1973) in their large series of patients. The reasons for this are not entirely clear but a number of patients in our series were referred to rheumatology and dermatology clinics in this hospital. Also all cases were systematically examined for evidence of scleroderma, which on the whole was relatively mild in manifestation, was not progressive, and did not distress the patients.

The original descriptions of scleroderma associated with primary biliary cirrhosis suggested that the patients had the CRST syndrome (Murray-Lyon et al., 1970; Reynolds et al., 1971) and that this was more benign and carried overall a good prognosis (Carr et al., 1965). In general the clinical course of our patients was benign. However, only 2 of our patients had calcinosis (Cases 10,12), both of whom had well marked oesophageal changes, and all the patients with telangiectasia had evidence of systemic involvement. We suggest, therefore, that the CRST syndrome is not a separate clinical subgroup with a different clinical course when associated with primary biliary cirrhosis but is part of the spectrum of disease in scleroderma. This is borne out by findings in patients with scleroderma unassociated with primary biliary cirrhosis (Rowell, 1976). It is unclear why scleroderma and primary biliary cirrhosis should be associated as no obvious differences in terms of age and sex distribution, length of history, or prognosis, between patients with and without scleroderma were found. The aetiology of both diseases is obscure.

A very high frequency of HLA A1 + B8 was found in our patients with scleroderma and primary biliary cirrhosis. In our previous study of 49 unselected patients with primary biliary cirrhosis (Galbraith et al., 1974) there was no significant difference in the frequency of these antigens. HLA B8 is associated with a heterogeneous group of disorders including myasthenia gravis, dermatitis herpetiformis, coeliac 
disease, juvenile diabetes, thyrotoxicosis, chronic active hepatitis, and sicca syndrome (Ryder and Svejgaard, 1976). The reason for the association is uncertain, as is its significance.

Antinuclear antibodies are frequently seen in scleroderma and are said to be mainly of the nucleolar or speckled patterns of staining (Beck et al., 1963). 8 of our patients with scleroderma had positive antinuclear antibodies on at least one occasion and one had nucleolar staining (Case 6) and 2 (Cases 11, 12) speckled staining. Some patients with the features of scleroderma may fall within the category of mixed connective tissue disorder (MCTD), described by Sharp et al. (1972). These patients show features of scleroderma, polymyositis, and systemic lupus erythematosus with the presence of a specific antibody to an extractable nuclear antigen as well as positive antinuclear antibodies. The disease is said to have a good prognosis. Only 2 of our patients (Cases 6,11 ) had ribonuclear protein antibodies. Our patients lacked the clinical evidence to be described as MCTD, confirming that ribonuclear protein antibodies are fairly nonspecific (Griffiths et al., 1977). Their presence may only represent a high level of tissue damage in patients who are immunologically abnormal and may be of no aetiological significance.

Keratoconjunctivitis sicca occurred in all the patients tested within the scleroderma group, except Case 14 who had atypical scleroderma. AlarconSegovia et al. (1974) stated that sicca is invariably found in scleroderma. We have presented evidence suggesting that this common complication of primary biliary cirrhosis may be due to an immune response directed at proteins in salivary glands which cross-react with other antigenic proteins in the liver, particularly in the bile ducts, which are preferentially involved in primary biliary cirrhosis (Golding et al., 1973; McFarlane et al., 1976). A similar mechanism, with an immune reaction in epithelial and mucosal lining cells, could give rise to the histological changes of scleroderma.

Although most of the patients were taking part in the clinical trial of azathioprine in the treatment of primary biliary cirrhosis which is continuing, the scleroderma was invariably present before the patient entered the trial and hence the association cannot be due to the treatment given.

The destructive arthropathy seen in 4 patients was striking. Ansell and Bywaters (1957) have described cystic bone disease in primary biliary cirrhosis associated with hypercholesterolaemia, noting the similarities in the invasion of bone by foam cells in the patients with Gaucher's disease, and reticulohistiocytosis. However, none of our 4 patients had any degree of hypercholesterolaemia. In the 2 patients who had surgery the histological picture of gross osteoarthrosis without obvious deposits ${ }^{3}$ of foam cells. The radiographic appearances are more of avascular necrosis. None of our patients had had local or systemic steroids to produce such a lesiø̈n. Zinn (1971), however, reported that $13 \%$ of कुis series of patients with avascular necrosis tad chronic liver disease, although he does not define कhe type of disease they had. It seems that primary bilighry cirrhosis should be added to the list of possible causes of avascular necrosis.

Finally, with respect to the inflammatory arthri $\vec{i}$ s, it can be argued that a group of patients composed predominantly of middle-aged females is likelyofo have a $5 \%$ prevalence of rheumatoid arthritis (Lawrence, 1961), which is very similar to the prevalence in this study. There seems to be tho specific inflammatory arthritis in primary biliäry cirrhosis, as has been suggested in chronic active hepatitis (Barnardo et al., 1973). What is more, arthralgia, which is a common presenting feature-in chronic active hepatitis (Whelton, 1970) was seen in our patients with primary biliary cirrhosis

We are indebted to Professor Deborah Doniach for the autoantibody tests, Dr Andre Peltier fow antiextractable nuclear antigen tests, Dr 9 . Batchelor and Miss Lesley Kennedy for fissme typing, and the consultant physicians who retored patients to us.

\section{References}

Alarcon-Segovia, D., Ibanez, G., Fernandez-Ortiz, $\overrightarrow{\bar{J}}$., Velazquez-Forero, F., and Gonzalez-Jimenez, Y. (19 $\$ 4)$. Sjögren's syndrome in progressive systemic sclerosis (scleroderma). American Journal of Medicine, 57, 78-8

Ansell, B. M., and Bywaters, E. G. L. (1957). Histiocytic bione and joint disease. Annals of the Rheumatic Diseases, 916, 503-510.

August, P. J. (1974). Primary biliary cirrhosis and sclefroderma. Proceedings of the Royal Society of Medicine,, 67 , 58.

Barnardo, D. E., Vernon-Roberts, B., and Currey, H. L-FF. (1973). A case of active chronic hepatitis with painiess erosive arthritis. Gut, 14, 800-804.

Bartholomew, L. G., Carn, J. C., Winkelman, R. K., and Baggenstoss, A. H. (1964). Chronic disease of the lover associated with systemic scleroderma. American Journatof Digestive Diseases, 9, 43-55.

Batchelor, J. R. (1973). Handbook of Experimental Immunology, 2nd ed., p. 32. Ed. by D. M. Weir. Blackwell, Oxfoged.

Beck, J. S., Anderson, J. R., Gray, K. B., and Rowell, N囚R. (1963). Antinuclear and precipitating autoantibodies $\omega_{\text {in }}$ progressive systemic sclerosis. Lancet, 2, 1180-1190.

Buffet, C., and Etienne, J-P. (1975). Manifestations extrahépatiques cliniques des hépatites chroniques et Ges cirrhosis biliaires primitives. Archives Francaises des Maladies de l'Appareil Digestif (Paris), 64, 539-547.

Carr, R. D., Hersel, E. B., and Stevenson, T. D. (196\$ㄱ). CRST syndrome-a benign variant of scleroder ma. Archives of Dermatology, 92, 519-525. 
D’Angelo, W. A., Fries, J. F., Nasi, A. T., and Shulman, L. E. (1969). Pathological observations in systemic sclerosis (scleroderma). American Journal of Medicine, 46, 428-440.

Galbraith, R. M., Eddleston, A. L. W. F., Smith, M. E. M., Williams, R., McSween, R. N. M., Watkinson, G., Dick, H., Dennedy, L. A., and Batchelor, J. R. (1974). Histocompatibility antigens in active chronic hepatitis and primary biliary cirrhosis. British Medical Journal, 3, 604-605.

Golding, P. L., Smith, M., and Williams, R. (1973). Multisystem involvement in chronic liver disease. American Journal of Medicine, 55, 772-782.

Griffiths, I. D., Mumford, P., Maini, R. N., and Scott, J. T. (1977). Clinical significance of antibodies to extractable nuclear antigens (ENA). (Abst.) Annals of the Rheumatic Diseases, 36, 479.

Lawrence, J. S. (1961). Prevalence of rheumatoid arthritis. Annals of the Rheumatic Diseases, 20, 11-17.

McFarlane, I. G., Wojcicka, B. M., Tsantoulas, D. C., Funk, C., Portman, B., Eddleston, A. L. W. F., and Williams, R. (1976). Cellular responses to salivary antigens in autoimmune liver disease with sicca syndrome. Clinical and Experimental Immunology, 25, 389-395.

Morgan, M. V. (1973). Primary biliary cirrhosis, scleroderma and keratoconjunctivitis sicca. Proceedings of the Royal Society of Medicine, 66, 1112.

Murray-Lyon, I. M., Thompson, R. P. H., Ansell, I. D., and Williams, R. (1970). Scleroderma and primary biliary cirrhosis. British Medical Journal, 3, 258-259.
O'Brien, S. T., Eddy, W. M., and Krawitt, E. L. (1972). Primary biliary cirrhosis associated with scleroderma. Gastroenterology, 62, 118-121.

Reynolds, T. B., Denison, E. K., Frankl, H. D., Lieverman, F. L., and Peters, R. L. (1971). Primary biliary cirrhosis with scleroderma, Raynaud's phenomenon and telangiectasia. American Journal of Medicine, 50, 302-312.

Rowell, N. R. (1976). The prognosis of systemic sclerosis. British Journal of Dermatology, 95, 57-60.

Ryder, L. P., and Svejgaard, A. (1976). Associalion Between $H L A$ and Disease. Copenhagen.

Sharp, G. C., Irvin, W. S., Tay, E. M., Gould, R. G., and Holman, H. R. (1972). Mixed connective tissue diseasean apparently distinct rheumatic disease syndrome associated with a specific antibody to an extractable nuclear antigen (ENA)). American Journal of Medicine, 52, 148-159.

Sherlock, S., and Scheuer, M. D. (1973). The presentation and diagnosis of 100 patients with primary biliary cirrhosis. New England Journal of Medicine, 289, 674-678.

Walker, J. G., Doniach, D., Roitt, I. M., and Sherlock, S. (1965). Serological tests in the diagnosis of primary biliary cirrhosis. Lancet, 1, 827-831.

Whelton, M. J. (1970). Arthropathy and liver disease. British Journal of Hospital Medicine, 3, 243-247.

Zinn, W. M. (1971). Idiopathic ischaemic necrosis of the femoral head in adults. Modern Trends in Rheumatology, 2nd ed., p. 348. Ed. by A. G. S. Hill. Butterworth, London. 